ARTICLE

\title{
Formation of large low shear velocity provinces through the decomposition of oxidized mantle
}

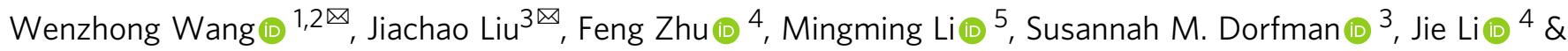 \\ Zhongqing $\mathrm{Wu}^{1,6,7 凶}$
}

Large Low Shear Velocity Provinces (LLSVPs) in the lowermost mantle are key to understanding the chemical composition and thermal structure of the deep Earth, but their origins have long been debated. Bridgmanite, the most abundant lower-mantle mineral, can incorporate extensive amounts of iron ( $\mathrm{Fe}$ ) with effects on various geophysical properties. Here our high-pressure experiments and ab initio calculations reveal that a ferric-iron-rich bridgmanite coexists with an Fe-poor bridgmanite in the 90 mol\% $\mathrm{MgSiO}_{3}-10 \mathrm{~mol}_{2} \mathrm{Fe}_{2} \mathrm{O}_{3}$ system, rather than forming a homogeneous single phase. The $\mathrm{Fe}^{3+}$-rich bridgmanite has substantially lower velocities and a higher $V_{P} / V_{S}$ ratio than $\mathrm{MgSiO}_{3}$ bridgmanite under lowermost-mantle conditions. Our modeling shows that the enrichment of $\mathrm{Fe}^{3+}{ }_{-}$-rich bridgmanite in a pyrolitic composition can explain the observed features of the LLSVPs. The presence of $\mathrm{Fe}^{3+}$-rich materials within LLSVPs may have profound effects on the deep reservoirs of redox-sensitive elements and their isotopes.

\footnotetext{
${ }^{1}$ Laboratory of Seismology and Physics of Earth's Interior, School of Earth and Space Sciences, University of Science and Technology of China, Hefei, China.

${ }^{2}$ Department of Earth Sciences, University College London, London, UK. ${ }^{3}$ Department of Earth and Environmental Sciences, Michigan State University, East Lansing, MI, USA. ${ }^{4}$ Department of Earth and Environmental Sciences, University of Michigan, Ann Arbor, MI, USA. ${ }^{5}$ School of Earth and Space Exploration, Arizona State University, Tempe, AZ, USA. ${ }^{6}$ National Geophysical Observatory at Mengcheng, University of Science and Technology of China, Hefei, China. ${ }^{7}$ CAS Center for Excellence in Comparative Planetology, USTC, Hefei, Anhui, China. ${ }^{凶}$ email: wz30304@mail.ustc.edu.cn; jiacliu09@gmail.com; wuzq10@ustc.edu.cn
} 
T he large low shear velocity provinces (LLSVPs) are two massive and mysterious regions sitting beneath Africa and the Pacific ${ }^{1-3}$ and occupy $\sim 3-9 \%$ of the volume of the Earth $^{3,4}$. They are characterized by their lower-than-average seismic wave velocities ${ }^{4}$ and extend by thousands of kilometers laterally and up to $>1000 \mathrm{~km}$ vertically above the core-mantle boundary $(\mathrm{CMB})^{3,4}$. As the largest seismic heterogeneities in the lower mantle, they may hold the key to understanding the thermal, chemical, and dynamical evolution of the Earth ${ }^{5,6,7}$. Different shear-wave tomography models ${ }^{4}$ have reached agreement that the shear-wave velocity anomaly $\left(\mathrm{d} \ln V_{S}\right)$ ranges from -0.5 to $-1.0 \%$ in the shallow part of LLSVPs, while it could be up to $-3.0 \%$ in the bottom part ${ }^{6}$. The compressional-wave tomography models also reveal negative anomalies of compressional-wave velocities $\left(V_{P}\right)\left(\right.$ refs. $\left.{ }^{8,9}\right)$, although the amplitude, shape, and geographical location of $V_{P}$ anomaly vary widely among different models $s^{5}$. The $V_{P}$ anomaly generally has a smaller amplitude than the $V_{S}$ anomaly, causing a high $\operatorname{dn} V_{S} / \operatorname{dn} V_{P}$ ratio 9 . In particular, waveform and travel-time seismic studies ${ }^{1,3,10-12}$ reveal that the LLSVPs have sharp edges along their margins, which is also supported by the large lateral $\mathrm{d} V_{S}$ gradients at the boundary of LLSVPs ${ }^{6}$.

The systematic and discontinuous contrasts in seismic properties indicate that the LLVSPs are likely composed of distinct chemical materials from the surrounding mantle ${ }^{11,13}$. A chemically distinct origin of the LLSVPs may be implicated by their density anomalies as well; however, large discrepancies for the density anomaly associated with the LLSVPs exist in the literature ${ }^{5}$. Recent tidal tomography based on body tide displacements ${ }^{14}$ found that the mean density of the lower twothirds of the two LLSVPs is $\sim 0.5 \%$ higher than that of the surrounding mantle. On the contrary, a study using Stoneley modes suggested an overall negative density anomaly within LLSVPs, without excluding the possibility of a high-density anomaly within the lowermost LLSVPs ${ }^{15}$. It is still unknown whether the regional differences in density anomaly are caused by the choice of observations used to constrain density models or reflect the nature of LLSVPs associated with their origins.

Hypotheses for the origin of chemically distinct LLSVPs include processes associated with the accumulation of subducted oceanic crust over Earth history ${ }^{16}$ and the differentiation and solidification of an ancient basal magma ocean ${ }^{6}$. Sunken piles of subducted oceanic crust, which is compositionally different from and significantly denser than the pyrolitic lower mantle ${ }^{17}$, was proposed to explain LLSVPs because of the low velocity of calcium silicate perovskite $\left(\mathrm{CaSiO}_{3}, \mathrm{CaPv}\right)\left(\mathrm{ref} .{ }^{18}\right)$. However, there are significant discrepancies in the velocity of $\mathrm{CaPv}$ between two experimental studies ${ }^{18,19}$ and between experiments and theoretical results ${ }^{20}$. Elastic properties from ab initio simulations for the entire MORB assemblage indicate that subducted oceanic crust has relatively higher velocities than the ambient mantle ${ }^{21}$. Moreover, geodynamic simulations ${ }^{22}$ suggested that the presentday subducted oceanic crust is too thin to provide enough negative buoyancy to survive viscous stirring and it hence is difficult to amass coherent thermochemical structures and shapes at the CMB similar to LLSVPs ${ }^{23}$. Alternatively, LLSVPs may be composed of primordial residues from basal magma ocean crystallization or core-mantle differentiation that have not yet been fully homogenized by the mantle convection ${ }^{24-26}$. These primordial materials would need to be intrinsically more dense than the surrounding mantle to overcome mantle stirring ${ }^{27}$. Dense $\mathrm{Fe}-\mathrm{Ni}-\mathrm{S}$ liquid, for instance, was proposed to explain the LLSVPs $^{28}$, but the amount of this liquid remaining in the deep mantle, which depends on the drainage of melt to the core ${ }^{29}$, is under debate.

Consistent with both efficient drainage of metallic melt and a primordial origin of the LLSVPs is chemical heterogeneity produced by redox reactions in the magma ocean. Ferrous iron $\left(\mathrm{Fe}^{2+}\right)$ in silicate melts has been observed to disproportionate to ferric iron $\left(\mathrm{Fe}^{3+}\right)$ plus metallic iron $\left(\mathrm{Fe}^{0}\right)$ at high pressures ${ }^{30}$. Segregation of precipitated $\mathrm{Fe}^{0}$ from the magma ocean into the core would enrich $\mathrm{Fe}^{3+}$ in the mantle. Bridgmanite (Bdg), the dominant $\mathrm{Fe}^{3+}$-bearing mantle mineral, hosts $\mathrm{Fe}^{3+}$ through the $\mathrm{Fe}^{3+}-\mathrm{Fe}^{3+}$ or $\mathrm{Fe}^{3+}-\mathrm{Al}^{3+}$ charge-coupled substitution in the deep mantle ${ }^{31-35}$. In particular, a $\mathrm{Fe}^{3+}$-rich $\mathrm{Bdg}$ with the chemical composition of $\left(\mathrm{Mg}_{0.5} \mathrm{Fe}_{0.5}\right)\left(\mathrm{Si}_{0.5} \mathrm{Fe}_{0.5}\right) \mathrm{O}_{3}$ was recently synthesized by Liu et al. ${ }^{36}$. Oxidized domains enriched with such $\mathrm{Fe}^{3+}$-rich Bdg would be distinct from a pyrolitic lower mantle in sound velocity and density ${ }^{37,38}$ and may be responsible for the origins of lower-mantle seismic and geochemical heterogeneities, such as the LLSVPs ${ }^{1-3,6}$. The conditions of formation of such $\mathrm{Fe}^{3+}$-rich Bdg in a mantle phase assemblage and its elastic properties at lower-mantle-relevant temperatures are vital to test this hypothesis, but these questions remain unclear.

In this work, we combine high pressure-temperature $(P-T)$ experiments, ab initio calculations, and geodynamic simulations to study the formation of $\mathrm{Fe}^{3+}$-rich Bdg, its thermoelastic properties, and its dynamics in the mantle, to evaluate whether enrichment in $\mathrm{Fe}^{3+}$-rich Bdg can explain the seismic signatures of LLSVPs.

\section{Results}

The coexistence of $\mathrm{Fe}^{3+}$-rich and $\mathrm{Fe}$-poor bridgmanite phases. We conducted a series of multi-anvil experiments with the bulk composition of $90 \mathrm{~mol} \% \mathrm{MgSiO}_{3}-10 \mathrm{~mol} \% \mathrm{Fe}_{2} \mathrm{O}_{3}$ from $10-24$ $\mathrm{GPa}$ along a mantle geotherm (Supplementary Table 1). At 10 GPa and $1573 \mathrm{~K}$ (Fig. 1d), the run products consist of separate $\mathrm{MgSiO}_{3}$ and $\mathrm{Fe}_{2} \mathrm{O}_{3}$ phases, demonstrating low solubility of $\mathrm{Fe}_{2} \mathrm{O}_{3}$ in clinopyroxenes at upper-mantle conditions due to the incompatibility between large $\mathrm{Fe}^{3+}$ and small tetrahedral site. At $15 \mathrm{GPa}$, an iron-rich akimotoite (Aki) forms with $33 \mathrm{~mol} \%$ of $\mathrm{MgSiO}_{3}$ and $67 \mathrm{~mol} \%$ of $\mathrm{Fe}_{2} \mathrm{O}_{3}$, coexisting with $\left(\mathrm{Mg}_{1.79} \mathrm{Fe}_{0.18}\right) \mathrm{SiO}_{4}$ wadsleyite and $\mathrm{SiO}_{2}$ stishovite (Fig. 1c). This indicates that the iron-rich Aki coexisting with iron-depleted oxides/silicates are energetically more stable than a single-phase $\mathrm{MgSiO}_{3}-\mathrm{Fe}_{2} \mathrm{O}_{3}$ solid solution with intermediate iron content. At $24 \mathrm{GPa}$ and $1873 \mathrm{~K}$, which corresponds to the $P-T$ conditions around the uppermost lower mantle, the products consist of Fe-poor Bdg and Fe-rich Aki with $44-49 \mathrm{~mol} \% \mathrm{Fe}$ in both $\mathrm{Mg}$ and Si sites (Fig. 1a and Supplementary Table 1), instead of forming a single phase of $\left(\mathrm{Mg}_{0.9} \mathrm{Fe}_{0.1}\right)\left(\mathrm{Si}_{0.9} \mathrm{Fe}_{0.1}\right) \mathrm{O}_{3}$ Bdg. The Fe-rich Aki is evenly distributed in the matrix of the Fe-poor Bdg (Fig. 1a). The run products of experiments running at the same $P-T$ conditions for 8 and $24 \mathrm{~h}$ have the same compositions within analytical uncertainty (Supplementary Table 1), confirming that the experiments reached equilibrium. In situ XRD measurements coupled with a diamond anvil cell (DAC) show that this Fe-rich Aki phase transforms to Bdg phase at $23.5 \pm 1.0 \mathrm{GPa}$ and $300 \mathrm{~K}$ (Supplementary Fig. 1). Moreover, this $\mathrm{Fe}^{3+}{ }_{-}$-rich Bdg phase completely transforms back to Aki with the same lattice parameters as the starting Aki phase after the decompression of the DAC (Supplementary Fig. 1). The reversible phase transition of this Fe-rich phase means that for our multi-anvil experiments at the $P-T$ conditions of the uppermost lower mantle, $\mathrm{Fe}^{3+}$-rich Bdg coexists with Fe-pool Bdg.

A previous multi-anvil study ${ }^{39}$ synthesized $\mathrm{Fe}^{3+}$-only bridgmanite with $2-4 \mathrm{~mol} \% \mathrm{Fe}^{3+}$ in the cation sites but did not observe the $\mathrm{Fe}^{3+}{ }_{\text {-rich }} \mathrm{Bdg}$ phase, possibly because the bulk $\mathrm{Fe}$ content of their experiments is not high enough to enable the formation of such $\mathrm{Fe}^{3+}{ }_{\text {-rich }} \mathrm{Bdg}$. Moreover, the presence of unreacted $\mathrm{MgO}$ and $\mathrm{SiO}_{2}$ in their run products (Fig. 1 in ref. ${ }^{39}$ ) suggests that their starting materials may not be homogenous or 



Fig. 1 Back-scattered scanning electron microscope images of recovered experimental phase assemblages forming from $90 \% \mathrm{MgSiO}_{3}+10 \% \mathrm{Fe}_{2} \mathrm{O}_{3}$ starting mixture after equilibrium at mantle pressure-temperature conditions for $\mathbf{6 - 1 0} \mathbf{~ h}$. Bridgmanite/akimotoite with $\sim 50$ mol\% $\mathrm{Fe}_{2} \mathrm{O}_{3}$ substitution in both $\mathrm{Mg}$ and Si sites (bright phases in (a-c)) coexists with normal mantle minerals such as Fe-poor bridgmanite (dark phases in (a) and (b)) at $>20 \mathrm{GPa}$, or with wadsleyite (gray phase in (c)) + stishovite (dark phase in (c)) at $15 \mathrm{GPa}$, while $\mathrm{Fe}_{2} \mathrm{O}_{3}$ (bright phase in (d)) was stabilized as a separate phase with Fe-depleted clinopyroxene (dark phase in (d)) at $10 \mathrm{GPa}$

their experiments did not reach chemical equilibrium. Another study ${ }^{40}$ synthesized $\mathrm{Fe}^{3+}$-only Bdg with the starting material of $90 \mathrm{~mol} \% \mathrm{MgSiO}_{3}-10 \mathrm{~mol} \% \mathrm{Fe}_{2} \mathrm{O}_{3}$ using laser-heated diamond anvil cell (LH-DAC) ${ }^{40}$. However, the chemical composition of $\mathrm{Fe}^{3+}$-only Bdg was not reported, possibly because there was a significant loss of $\mathrm{Fe}$ and $\mathrm{Mg}$ during melting ${ }^{40}$, and some $\mathrm{Fe}^{3+}$ was reduced through reaction with diamond during laser heating ${ }^{41}$. In addition, the proportion of the Fe-rich Bdg phase is much smaller than the Fe-poor Bdg (Fig. 1), and therefore it is difficult to detect without a detailed analysis of the run products in ref. ${ }^{40}$.

We also performed ab initio calculations (see methods and supplementary materials) to investigate the stability of $\left(\mathrm{Mg}_{0.5} \mathrm{Fe}_{0.5}\right)\left(\mathrm{Si}_{0.5} \mathrm{Fe}_{0.5}\right) \mathrm{O}_{3}$ Bdg under lower-mantle conditions. Our results show that the assemblage of $\left(\mathrm{Mg}_{0.5} \mathrm{Fe}_{0.5}\right)\left(\mathrm{Si}_{0.5} \mathrm{Fe}_{0.5}\right) \mathrm{O}_{3}$ and $\mathrm{MgSiO}_{3}$ Bdg has a lower Gibbs free energy than a singlephase $\left(\mathrm{Mg}_{0.875} \mathrm{Fe}_{0.125}\right)\left(\mathrm{Si}_{0.875} \mathrm{Fe}_{0.125}\right) \mathrm{O}_{3}$ Bdg under the $P-T$ of the whole lower mantle regardless of the spin state (Supplementary Fig. 2), indicating that the mixed two phases are more stable than the single-phase Bdg with a homogeneous composition. The theoretical results support our experimental observations and reveal that this $\mathrm{Fe}^{3+}$-rich Bdg with the chemical composition of approximately $\left(\mathrm{Mg}_{0.5} \mathrm{Fe}_{0.5}\right)\left(\mathrm{Si}_{0.5} \mathrm{Fe}_{0.5}\right) \mathrm{O}_{3}$ should form as a separate phase coexisting with Fe-poor Bdg in the bulk composition of $90 \mathrm{~mol} \% \mathrm{MgSiO}_{3}-10 \mathrm{~mol} \% \mathrm{Fe}_{2} \mathrm{O}_{3}$ due to the miscibility gap.

Elastic properties and sound velocities of $\left(\mathrm{Mg}_{0.5} \mathrm{Fe}_{0.5}\right)$ $\left(\mathbf{S i}_{0.5} \mathrm{Fe}_{0.5}\right) \mathrm{O}_{3}$ bridgmanite. Determining the seismic signature of a separate $\mathrm{Fe}^{3+}$-rich phase in equilibrium with the mantle phase assemblage requires elastic properties of this phase as a function of pressure and temperature conditions in the mantle. The elastic properties of $\left(\mathrm{Mg}_{0.5} \mathrm{Fe}_{0.5}\right)\left(\mathrm{Si}_{0.5} \mathrm{Fe}_{0.5}\right) \mathrm{O}_{3}$ Bdg up to $130 \mathrm{GPa}$ and $3000 \mathrm{~K}$ were theoretically obtained from ab initio calculations.
Because Bdg may also accommodate $\mathrm{Al}$ in the octahedral site ${ }^{31,38,42}$, we also conducted calculations on an end-member composition $\left(\mathrm{Mg}_{0.5} \mathrm{Fe}_{0.5}\right)\left(\mathrm{Si}_{0.5} \mathrm{Al}_{0.5}\right) \mathrm{O}_{3}$, to quantify the effect of $\mathrm{Al}$ on the elasticity of Bdg. In these calculations, the octahedral site (B-site) $\mathrm{Fe}^{3+}$ in $\left(\mathrm{Mg}_{0.5} \mathrm{Fe}_{0.5}\right)\left(\mathrm{Si}_{0.5} \mathrm{Fe}_{0.5}\right) \mathrm{O}_{3}$ Bdg undergoes a highspin (HS) state to a low-spin (LS) state transition with increasing pressure (Fig. 2a), while the dodecahedral-site (A-site) $\mathrm{Fe}^{3+}$ in both compositions remain in the HS state throughout the lowermantle conditions ${ }^{43}$.

Our calculated volumes of HS- and LS- $\left(\mathrm{Mg}_{0.5} \mathrm{Fe}_{0.5}\right)\left(\mathrm{Si}_{0.5} \mathrm{Fe}_{0.5}\right)$ $\mathrm{O}_{3}$ Bdg agree well with experimental measurements at $300 \mathrm{~K}$ (ref. ${ }^{36}$ ) (Fig. 2a). The calculated spin transition of the B-site $\mathrm{Fe}^{3+}$ occurs between 49 and $55 \mathrm{GPa}$ at $300 \mathrm{~K}^{36}$, which is slightly higher and narrower than experimental results ${ }^{36}$. The predicted volume collapse $\left(\Delta V^{\mathrm{HS}-\mathrm{LS}}\right)$ caused by the spin transition of B-site $\mathrm{Fe}^{3+}$ is $\sim 4.3 \%$ at $300 \mathrm{~K}$, higher than experimental measurements $(2.7 \%)^{36}$ but consistent with previous theoretical calculations ${ }^{44}$ on $\left(\mathrm{Mg}_{0.5} \mathrm{Fe}_{0.125}\right)\left(\mathrm{Si}_{0.5} \mathrm{Fe}_{0.125}\right) \mathrm{O}_{3}$ Bdg assuming that $\Delta V^{\mathrm{HS}-\mathrm{LS}}$ is linearly dependent on $\mathrm{Fe}^{3+}$ content. The $\Delta V^{\mathrm{HS}-\mathrm{LS}}$ discrepancy between experimental and theoretical studies is probably caused by the difference in the pressure range for the mixed-spin (MS) state. The predicted volumes of $\left(\mathrm{Mg}_{0.5} \mathrm{Fe}_{0.5}\right)\left(\mathrm{Si}_{0.5} \mathrm{Al}_{0.5}\right) \mathrm{O}_{3}$ Bdg also show excellent agreement with experimental results at $300 \mathrm{~K}^{42}$. These comparisons demonstrate the high reliability of our DFT $+U$ calculations in predicting elastic properties, as suggested by previous studies ${ }^{43-45}$

The spin transition of B-site $\mathrm{Fe}^{3+}$ in $\left(\mathrm{Mg}_{0.5} \mathrm{Fe}_{0.5}\right)\left(\mathrm{Si}_{0.5} \mathrm{Fe}_{0.5}\right) \mathrm{O}_{3}$ Bdg generates a strong effect on bulk modulus $\left(K_{S}\right)$ and $V_{P}$, which both show deep valleys that broaden and decrease in magnitude with increasing temperature (Supplementary Fig. 3). The magnitude and width of the $K_{S}$ and $V_{P}$ anomalies are controlled by the fraction of LS B-site $\mathrm{Fe}^{3+}\left(\mathrm{n}_{\mathrm{LS}}\right)$ and the pressure and temperature dependences of $\mathrm{n}_{\mathrm{LS}}$ (see Supplementary Materials). Compared to $\mathrm{MgSiO}_{3} \mathrm{Bdg}{ }^{46}$, both $\left(\mathrm{Mg}_{0.5} \mathrm{Fe}_{0.5}\right)\left(\mathrm{Si}_{0.5} \mathrm{Fe}_{0.5}\right) \mathrm{O}_{3}$ and 

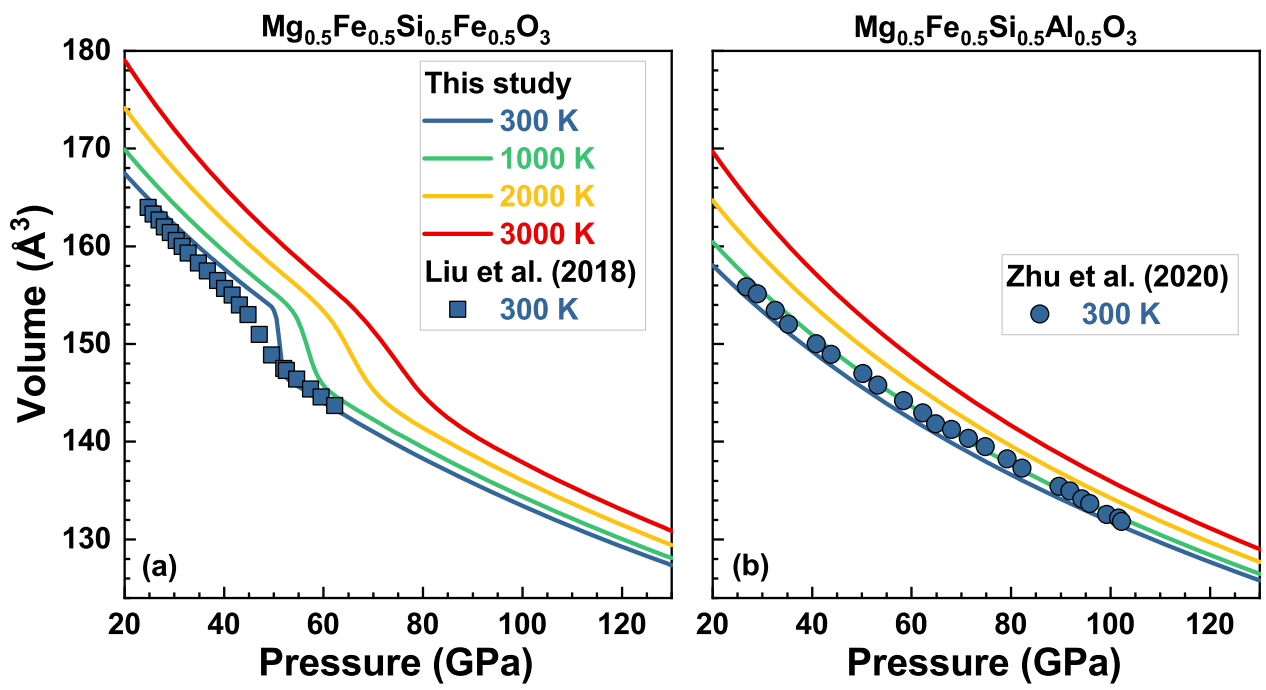

Fig. 2 Isothermal compression curves predicted by ab initio calculations for $\left(\mathrm{Mg}_{0.5} \mathrm{Fe}_{0.5}\right)\left(\mathrm{Si}_{0.5} \mathrm{Fe}_{0.5}\right) \mathrm{O}_{3}$ and $\left(\mathrm{Mg}_{0.5} \mathrm{Fe}_{0.5}\right)\left(\mathrm{Si}_{0.5} \mathrm{Al}_{0.5}\right) \mathrm{O}_{3}$ bridgmanite. a $\left(\mathrm{Mg}_{0.5} \mathrm{Fe}_{0.5}\right)\left(\mathrm{Si}_{0.5} \mathrm{Fe}_{0.5}\right) \mathrm{O}_{3}$ bridgmanite, $\mathbf{b}\left(\mathrm{Mg}_{0.5} \mathrm{Fe}_{0.5}\right)\left(\mathrm{Si}_{0.5} \mathrm{Al}_{0.5}\right) \mathrm{O}_{3}$ bridgmanite. The blue, green, orange, and red curves are calculated compression curves of $\left(\mathrm{Mg}_{0.5} \mathrm{Fe}_{0.5}\right)\left(\mathrm{Si}_{0.5} \mathrm{Fe}_{0.5}\right) \mathrm{O}_{3}$ and $\left(\mathrm{Mg}_{0.5} \mathrm{Fe}_{0.5}\right)\left(\mathrm{Si}_{0.5} \mathrm{Al}_{0.5}\right) \mathrm{O}_{3}$ bridgmanite at 300, 1000, 2000, and $3000 \mathrm{~K}$, respectively. The blue squares are experimental measurements from Liu et al. ${ }^{36}$, which shows that the spin transition of $\mathrm{Fe}^{3+}$ in the B-site of $\left(\mathrm{Mg}_{0.5} \mathrm{Fe}_{0.5}\right)\left(\mathrm{Si}_{0.5} \mathrm{Fe}_{0.5}\right) \mathrm{O}_{3}$ bridgmanite occurs between 43 and $53 \mathrm{GPa}$ at $300 \mathrm{~K}$. The blue circles are experimental results of Zhu et al. ${ }^{42}$.

$\left(\mathrm{Mg}_{0.5} \mathrm{Fe}_{0.5}\right)\left(\mathrm{Si}_{0.5} \mathrm{Al}_{0.5}\right) \mathrm{O}_{3} \mathrm{Bdg}$ have much lower elastic moduli $\left(K_{S}\right.$ and $G$ ) and velocities $\left(V_{P}\right.$ and $V_{S}$ ) (Supplementary Fig. 4). At lowermost-mantle conditions, the differences in $K_{S}, G, V_{P}$, and $V_{S}$ between $\left(\mathrm{Mg}_{0.5} \mathrm{Fe}_{0.5}\right)\left(\mathrm{Si}_{0.5} \mathrm{Fe}_{0.5}\right) \mathrm{O}_{3}$ and $\mathrm{MgSiO}_{3} \mathrm{Bdg}^{46}$ are about $-5 \%,-37 \%,-17 \%$, and $-28 \%$, respectively, which in turn causes a higher $V_{P} / V_{S}$ ratio of 2.1 in $\left(\mathrm{Mg}_{0.5} \mathrm{Fe}_{0.5}\right)\left(\mathrm{Si}_{0.5} \mathrm{Fe}_{0.5}\right) \mathrm{O}_{3} \mathrm{Bdg}$ (Supplementary Fig. 4). By comparison, the differences in $K_{S}, G$, $V_{P}$, and $V_{S}$ between $\left(\mathrm{Mg}_{0.5} \mathrm{Fe}_{0.5}\right)\left(\mathrm{Si}_{0.5} \mathrm{Al}_{0.5}\right) \mathrm{O}_{3}$ and $\mathrm{MgSiO}_{3} \mathrm{Bdg}$ are about $-4 \%,-18 \%,-9 \%$, and $-14 \%$, respectively.

\section{Discussion}

Combining elastic data from previous studies $20,45-47$ with our results, we modeled the density and velocity anomalies caused by the presence of $\mathrm{Fe}^{3+}$-rich $\mathrm{Bdg}$ relative to the pyrolitic composition, which can effectively reproduce the reference seismic velocities and density of PREM $^{37,38}$. The modeled chemical assemblage has pyrolitic mineral fractions (15\% ferropericlase $(\mathrm{Fp})+78 \% \mathrm{Bdg}+7 \% \mathrm{CaPv})$ in which a portion of $\mathrm{Fe}^{2+}$-bearing Bdg was substituted by $\left(\mathrm{Mg}_{0.5} \mathrm{Fe}_{0.5}\right)\left(\mathrm{Si}_{0.5} \mathrm{Fe}_{0.5}\right) \mathrm{O}_{3} \mathrm{Bdg}$. We find that the enrichment of $\left(\mathrm{Mg}_{0.5} \mathrm{Fe}_{0.5}\right)\left(\mathrm{Si}_{0.5} \mathrm{Fe}_{0.5}\right) \mathrm{O}_{3} \mathrm{Bdg}$ in the assemblage can explain the seismic features of the LLSVPs ${ }^{4,6,8,9}$. The $V_{S}$ anomalies of $-1.5 \%$ to $-3.0 \%$ and the large $\operatorname{dln} V_{S} / \mathrm{d} \ln V_{P}$ ratio $>2.0$ observed in LLSVPs ${ }^{4,6,8,9}$ can be reproduced by the enrichment of $10-15 \%\left(\mathrm{Mg}_{0.5} \mathrm{Fe}_{0.5}\right)\left(\mathrm{Si}_{0.5} \mathrm{Fe}_{0.5}\right) \mathrm{O}_{3} \mathrm{Bdg}$ in pyrolite at $110 \mathrm{GPa}$ (Fig. 3). If LLSVPs are hotter $\left(\Delta T_{\text {LLSVPS }}>0\right)$, the required proportion of $\left(\mathrm{Mg}_{0.5} \mathrm{Fe}_{0.5}\right)\left(\mathrm{Si}_{0.5} \mathrm{Fe}_{0.5}\right) \mathrm{O}_{3} \quad \mathrm{Bdg}$ would accordingly decrease; for example, it will decrease by $\sim 2 \%$ if $\Delta T_{\text {LLSVPS }}$ is $+400 \mathrm{~K}$. For a pyrolitic composition, Bdg also contains $\sim 5 \mathrm{~mol} \% \mathrm{Al}_{2} \mathrm{O}_{3}$, which does not significantly change its velocities and density ${ }^{48}$. When $5 \mathrm{~mol} \% \mathrm{Al}_{2} \mathrm{O}_{3}$ is incorporated into $\mathrm{Bdg}$, the $V_{P}$ and $V_{S}$ anomalies caused by the presence of $15 \%$ $\left(\mathrm{Mg}_{0.5} \mathrm{Fe}_{0.5}\right)\left(\mathrm{Si}_{0.5} \mathrm{Fe}_{0.4} \mathrm{Al}_{0.1}\right) \mathrm{O}_{3} \mathrm{Bdg}$ at $\Delta T_{\text {LLSVPS }}$ equal to $+400 \mathrm{~K}$ will be $-1.5 \%$ and $-3.1 \%$ (Fig. 3 ), respectively, which can also reproduce the $d \ln V_{S} / \mathrm{d} \ln V_{P}$ ratio $>2.0$.

In addition, we find that the required proportion of $\left(\mathrm{Mg}_{0.5} \mathrm{Fe}_{0.5}\right)\left(\mathrm{Si}_{0.5} \mathrm{Fe}_{0.5}\right) \mathrm{O}_{3}$ Bdg increases with the decreasing of $\mathrm{Fe}^{2+}$ content in the modeled assemblage (noted by the $\mathrm{FeO}$ content in $\mathrm{Fp}, \mathrm{Fe}^{2+}{ }_{\mathrm{Fp}}$ ) to explain the same $V_{P}$ and $V_{S}$ anomalies (Fig. 4). If there is no $\mathrm{Fe}^{2+}$, the $\left(\mathrm{Mg}_{0.5} \mathrm{Fe}_{0.5}\right)\left(\mathrm{Si}_{0.5} \mathrm{Fe}_{0.5}\right) \mathrm{O}_{3}$ fraction that can reproduce the $V_{S}$ anomaly of $-3.0 \%$ would be raised to $\sim 17 \%$ at $\Delta T_{L L S V P S}$ equal to $+400 \mathrm{~K}$ (Fig. 4 and Supplementary Fig. 5), which corresponds to a $V_{P}$ anomaly of $\sim-1.0 \%$ and a $\mathrm{d} \ln V_{S} / \mathrm{d} \ln V_{P}$ ratio of $\sim 3.0$. The $\operatorname{d} \ln V_{S} / \mathrm{d} \ln V_{P}$ ratio $>2.0$ tends to be reproduced at relatively low $\mathrm{Fe}^{2+}$ contents (Fig. 4). If $\mathrm{Fe}^{2+}{ }_{\mathrm{Fp}} / \mathrm{Fe}^{2}$ $+_{\mathrm{Fp}, \mathrm{NM}}>0.9\left(\mathrm{Fe}^{2+} \mathrm{Fp}, \mathrm{NM}\right.$ is the $\mathrm{FeO}$ content of $\mathrm{Fp}$ in a normal pyrolitic lower mantle, $18 \mathrm{~mol} \%)$, the $\operatorname{d} \ln V_{S} / \mathrm{d} \ln V_{P}$ ratio is less than 2.0. In contrast, when $\mathrm{Fe}^{2+}{ }_{\mathrm{Fp}} / \mathrm{Fe}^{2+}{ }_{\mathrm{Fp}, \mathrm{NM}}$ is $<0.25$, the $\mathrm{d} \ln V_{S} /$ $\operatorname{d} \ln V_{P}$ ratio $>2.0$ can be reproduced for different $V_{S}$ anomalies (Fig. 4). Our modeling implies that the enrichment of $\left(\mathrm{Mg}_{0.5} \mathrm{Fe}_{0.5}\right)$ $\left(\mathrm{Si}_{0.5} \mathrm{Fe}_{0.5}\right) \mathrm{O}_{3} \mathrm{Bdg}$ in the pyrolite assemblage with relatively lower $\mathrm{Fe}^{2+}$ content can explain the velocity anomalies and the $\operatorname{dn} V_{S}$ l $\mathrm{d} \ln V_{P}$ ratio observed in LLSVPs ${ }^{4,6,8,9}$.

In contrast to velocity anomalies, the modeled density anomaly $(\operatorname{dln} \rho)$ could be positive, zero, or negative, depending on the $\left(\mathrm{Mg}_{0.5} \mathrm{Fe}_{0.5}\right)\left(\mathrm{Si}_{0.5} \mathrm{Fe}_{0.5}\right) \mathrm{O}_{3}$ abundance, temperature anomaly, and the fraction of $\mathrm{Fe}^{2+}$ in $\mathrm{Fp}$. To produce a $V_{S}$ anomaly of $-3.0 \%$ for the assemblage enriched in $\left(\mathrm{Mg}_{0.5} \mathrm{Fe}_{0.5}\right)\left(\mathrm{Si}_{0.5} \mathrm{Fe}_{0.5}\right) \mathrm{O}_{3} \mathrm{Bdg}$, the dln $\rho$ decreases from $+1.2 \%$ at $\Delta T_{\text {LLSVPS }}$ of $0 \mathrm{~K}$ and $\mathrm{Fe}^{2+}{ }_{\mathrm{Fp}} / \mathrm{Fe}^{2+}{ }_{\mathrm{Fp}, \mathrm{NM}}$ of 0.5 to $-0.5 \%$ at $\Delta T_{\text {LLSVPS }}$ of $+400 \mathrm{~K}$ and $\mathrm{Fe}^{2+}{ }_{\mathrm{Fp}} / \mathrm{Fe}^{2+}{ }_{\mathrm{Fp}}$, NM of 0.0 (Figs. 3, 4 and Supplementary Fig. 5). In general, the density anomaly is correlated with the magnitude of $V_{S}$ anomalies. For $\operatorname{dn} V_{S}<-1.0 \%$, the $\operatorname{dln} \rho$ could be positive if $\Delta T_{\text {LLSVPS }}$ is $0 \mathrm{~K}$; however, if $\Delta T_{\text {LLSVPS }}$ equals to $+400 \mathrm{~K}$, the dln $\rho$ could be positive only when $\operatorname{d} \ln V_{S}$ is $<-2.5 \%$ (Fig. 4). Our modeling suggests that the lowermost parts of LLSVPs with large negative velocity anomalies $(<-3.0 \%)^{4,6,8}$ could be denser than the ambient mantle, while the relatively shallow part of LLSVPs with -0.5 to $-1.0 \% V_{S}$ anomalies on average likely have slightly lighter density than the ambient mantle. Recent work proposed that the bottom two-thirds of the two LLSVPs are $\sim 0.5 \%$ denser than the surrounding mantle ${ }^{14}$, while Koelemeijer et al. ${ }^{15}$ argued that the overall density of the LLSVPs is lower than the surrounding mantle. Such different conclusions may be related to different depth sensitivities of the datasets considered ${ }^{49}$, regardless of the input observations. Also, geodynamic modeling studies ${ }^{50,51}$ suggested that the density anomalies of the LLSVPs relative to the surrounding mantle could be positive near the top and bottom of the LLSVPs but neutral or slightly negative in the middle of the LLSVPs. The density of LLSVPs could also be laterally inhomogeneous due to their 

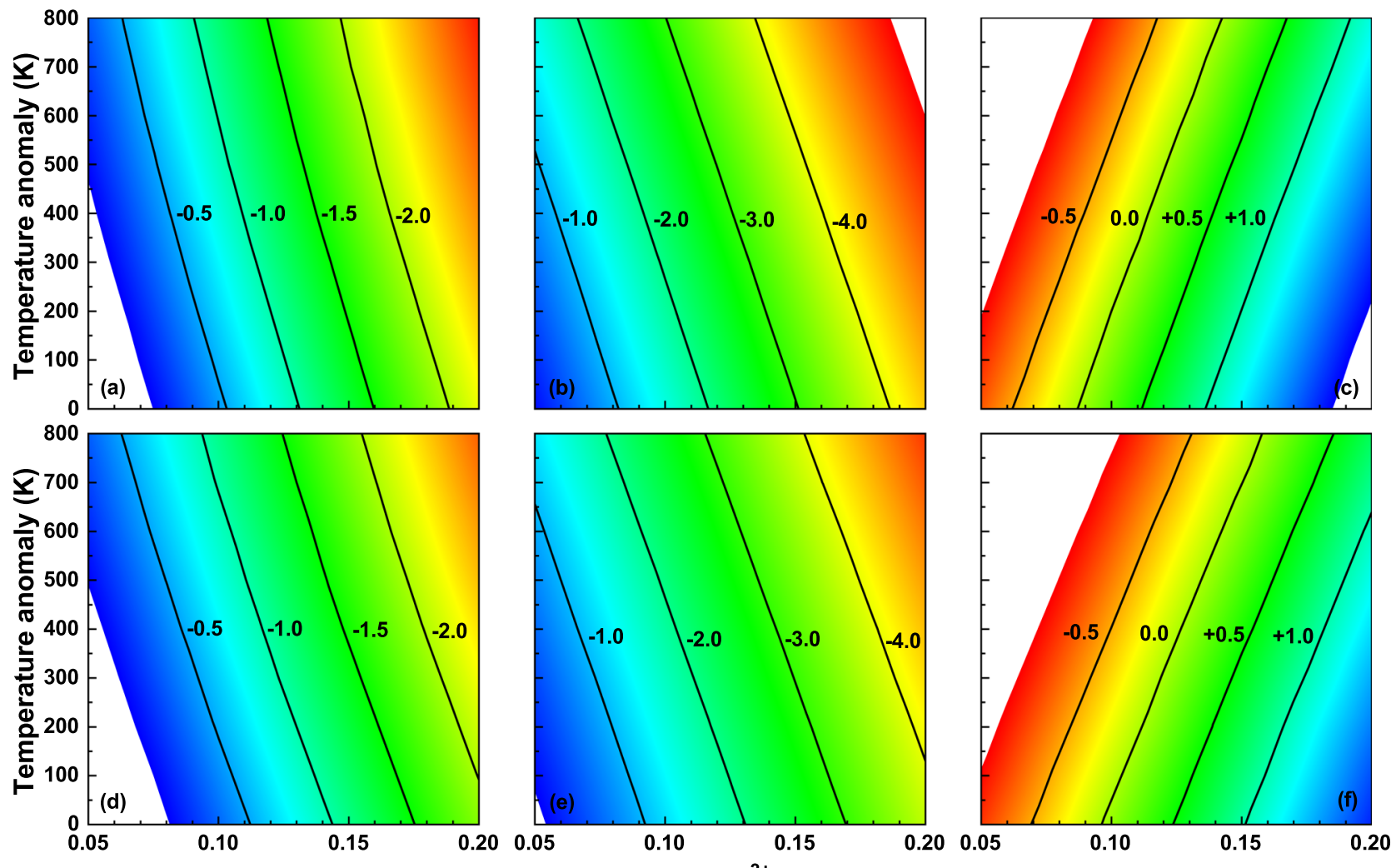

\section{Fraction of $\mathrm{Fe}^{3+}$-rich Bdg}


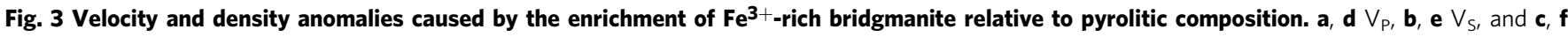
density anomalies at $110 \mathrm{GPa}$. a-c Anomalies due to enrichment of $\left(\mathrm{Mg}_{0.5} \mathrm{Fe}_{0.5}\right)\left(\mathrm{Si}_{0.5} \mathrm{Fe}_{0.5}\right) \mathrm{O}_{3}$ bridgmanite (Bdg); $\mathbf{d}-\mathbf{f}$ anomalies due to enrichment of $\left(\mathrm{Mg}_{0.5} \mathrm{Fe}_{0.5}\right)\left(\mathrm{Si}_{0.5} \mathrm{Fe}_{0.4} \mathrm{Al}_{0.1}\right) \mathrm{O}_{3} \mathrm{Bdg}$, where $5 \% \mathrm{Al}_{2} \mathrm{O}_{3}$ is incorporated into $\left(\mathrm{Mg}_{0.5} \mathrm{Fe}_{0.5}\right)\left(\mathrm{Si}_{0.5} \mathrm{Fe}_{0.5}\right) \mathrm{O}_{3}$. Velocities and density of the pyrolitic lower mantle are calculated using the best-fit composition of the lower mantle (15\% $\mathrm{Mg}_{0.82} \mathrm{Fe}_{0.18} \mathrm{O}$ ferropericlase ( $\mathrm{Fp}$ ), $78 \% \mathrm{Mg}_{0.92} \mathrm{Fe}_{0.08} \mathrm{SiO}_{3}$ bridgmanite $\left(\mathrm{Fe}^{2+}{ }_{-} \mathrm{Bdg}_{\mathrm{d}}\right.$ ), and $7 \% \mathrm{CaSiO}_{3} \mathrm{Ca}$-perovskite $\left.(\mathrm{CaPv})\right)^{37}$. The modeling chemical assemblage has pyrolitic mineral fractions in which a portion of Fe ${ }^{2+}$-bearing Bdg was substituted by $\left(\mathrm{Mg}_{0.5} \mathrm{Fe}_{0.5}\right)\left(\mathrm{Si}_{0.5} \mathrm{Fe}_{0.5}\right) \mathrm{O}_{3}$ or $\left(\mathrm{Mg}_{0.5} \mathrm{Fe}_{0.5}\right)\left(\mathrm{Si}_{0.5} \mathrm{Fe}_{0.4} \mathrm{Al}_{0.1}\right) \mathrm{O}_{3} \mathrm{Bdg}$. The initial $\mathrm{Fe}^{2+} \mathrm{O}$ contents of $\mathrm{Bdg}$ and $\mathrm{Fp}$ in the modeling assemblage are 4 and 9 mol\%, respectively, which are half of those in the reference pyrolite ${ }^{37}$. The temperature anomaly is with respect to the normal mantle temperature from Brown and Shankland ${ }^{74}$. Data for elasticity at high pressure and temperature are derived from previous theoretical studies: $\mathrm{Fp}$, ref. ${ }^{47} ; \mathrm{Fe}^{2+}$-Bdg, ref. ${ }^{46}$; $\mathrm{CaPv}$, ref. 20

internal convection and the entrainment of multiple compositional components into the LLSVPs ${ }^{52}$.

The present model for chemical heterogeneities within the LLSVPs is consistent with Fe-rich remnants of a basal magma ocean created early in Earth's history ${ }^{6,24-26}$. Ferrous Fe in dense silicate melts associated with the basal magma ocean would partially disproportionate to $\mathrm{Fe}^{3+}$ plus $\mathrm{Fe}^{0}$ at high pressures ${ }^{30}$ and segregation of precipitated $\mathrm{Fe}^{0}$ from the magma ocean into core would enrich silicate melt in $\mathrm{Fe}_{2} \mathrm{O}_{3}$ component. A thermodynamic model of magma ocean crystallization ${ }^{53}$ suggests that the silicate melt fraction would be gradually enriched in iron with $\mathrm{Fe} /$ $(\mathrm{Fe}+\mathrm{Mg})>0.3$ in the lower mantle after $60 \mathrm{wt} \%$ of the melt has solidified. The $\mathrm{Fe} /(\mathrm{Fe}+\mathrm{Mg})$ ratio in the residual melt remaining in the lowermost mantle could be up to 0.5 near the end of the crystallization. The amount of $\mathrm{Fe}^{3+}$ in this melt depends on the amount of $\mathrm{Fe}^{2+}$ that would disproportionate into $\mathrm{Fe}^{3+}$ plus $\mathrm{Fe}^{0}$ and the efficiency of $\mathrm{Fe}^{0}$ droplet segregation. The required bulk composition with $\mathrm{MgSiO}_{3}: \mathrm{Fe}_{2} \mathrm{O}_{3}$ equal to 9:1 could be produced when $40-80 \% \mathrm{Fe}^{2+}$ undergoes the disproportionation reaction and all $\mathrm{Fe}^{0}$ migrates into the core. $\mathrm{Fe}^{3+}$ would be incorporated into bridgmanite with further crystallization, and our experiments and ab initio calculations indicate that in these $\mathrm{Fe}^{3+}$-rich regions, a portion of $\left(\mathrm{Mg}_{0.5} \mathrm{Fe}_{0.5}\right)\left(\mathrm{Si}_{0.5} \mathrm{Fe}_{0.5}\right) \mathrm{O}_{3}$ silicate would form as a separate phase, coexisting with $\mathrm{Fe}^{3+}$-poor silicate. Due to the large excess density, $\left(\mathrm{Mg}_{0.5} \mathrm{Fe}_{0.5}\right)\left(\mathrm{Si}_{0.5} \mathrm{Fe}_{0.5}\right) \mathrm{O}_{3}$ silicate could descend to the base of the lower mantle through mantle convection and result in $\mathrm{Fe}^{3+}$-rich bridgmanite piles. Our geodynamic modeling demonstrates that such $\mathrm{Fe}^{3+}$-rich piles with $\sim 18 \%\left(\mathrm{Mg}_{0.5} \mathrm{Fe}_{0.5}\right)$ $\left(\mathrm{Si}_{0.5} \mathrm{Fe}_{0.5}\right) \mathrm{O}_{3} \mathrm{Bdg}$, which is $\sim 1.5 \%$ intrinsically denser than the ambient mantle (Fig. 4c), could form large-scale thermochemical structures in the lowermost mantle without being mixed into the background mantle throughout Earth's history (Fig. 5), which may accumulate to form LLSVPs.

Our findings imply that the segregation of $\mathrm{Fe}^{3+}{ }_{\text {-rich }}$ domains may cause heterogeneity in the redox states of the Earth's mantle, that is, the oxygen fugacity of the lowermost mantle may not be as low as inferred in previous studies ${ }^{54,55}$. We also expect these $\mathrm{Fe}^{3+}$-rich domains to be enriched in heavy iron isotopes because $\mathrm{Fe}^{3+}$ has a larger Fe force constant than $\mathrm{Fe}^{2+}$ (ref. ${ }^{56}$ ), which may affect the iron isotopic features of the deep Earth ${ }^{57}$. The presence of lower-mantle oxidizing heterogeneities would have profound effects on the cycles of volatiles ${ }^{30}$ and the deep reservoirs of redox-sensitive elements. For instance, the dense reduced $\mathrm{Fe}-\mathrm{C} / \mathrm{H} / \mathrm{S}$ melts formed at the mantle transition zone and shallow 

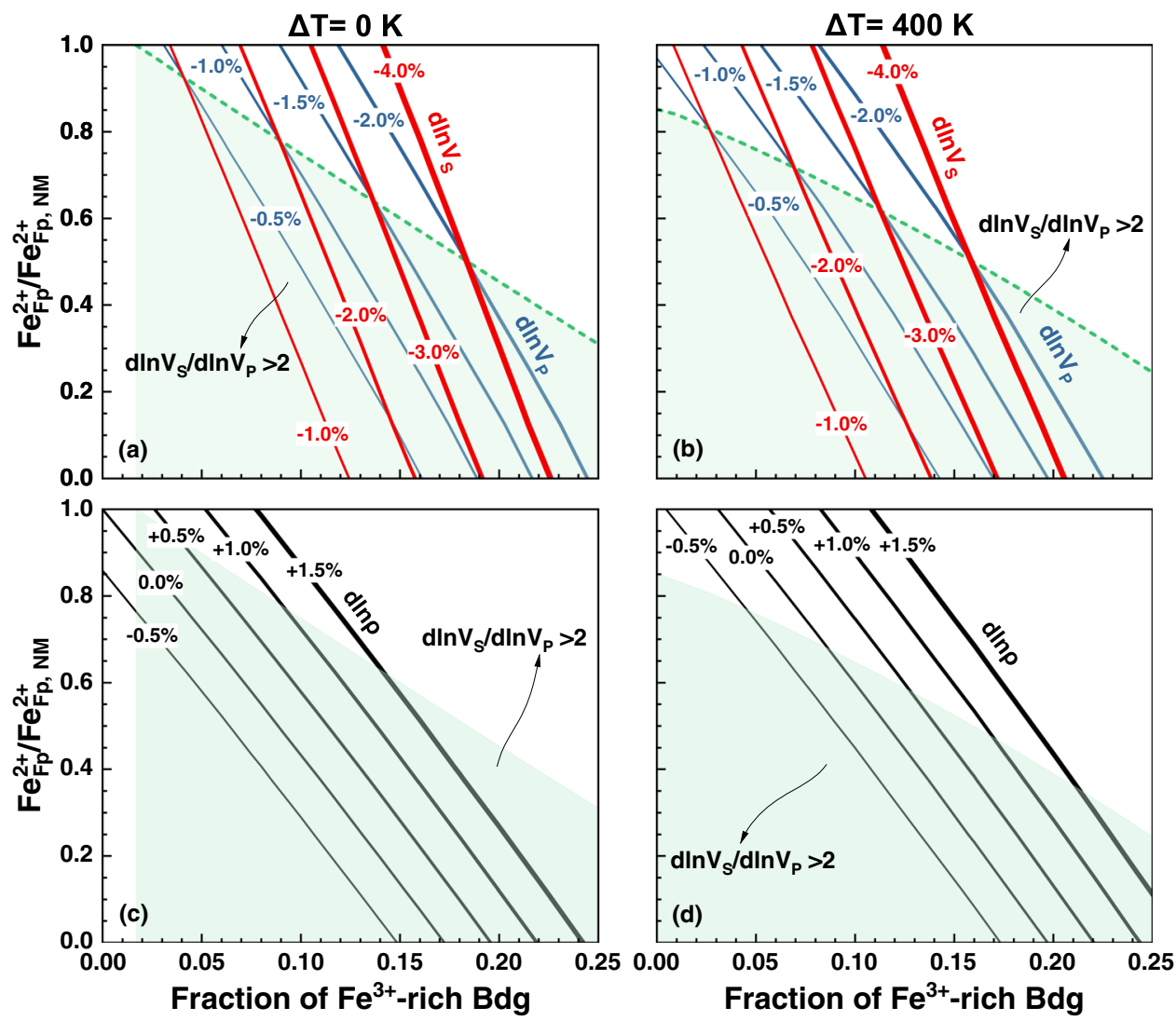

Fig. 4 Velocity and density anomalies versus $\mathbf{F e}^{2+}$ content and fraction of $\left(\mathbf{M g}_{\mathbf{0 . 5}} \mathbf{F e}_{\mathbf{0 . 5}}\right)\left(\mathbf{S i}_{\mathbf{0 . 5}} \mathbf{F e}_{\mathbf{0} .5}\right) \mathbf{O}_{\mathbf{3}}$ bridgmanite. a, $\mathbf{b} V_{P}$ and $V_{S}$ anomalies $($ solid blue and red lines, respectively); c, $\mathbf{d}$ density perturbation (solid black lines). The line thickness refers to the magnitude as noted by the number. $\mathbf{a}, \mathbf{c}$ Temperature anomaly is $0 \mathrm{~K}\left(\Delta T_{\text {LLSVPS }}=0 \mathrm{~K}\right) ; \mathbf{b}, \mathbf{d} \Delta T_{\text {LLSVPS }}=+400 \mathrm{~K}$. The pyrolitic lower mantle is composed of $15 \% \mathrm{Mg}_{0.82} \mathrm{Fe}_{0.18} \mathrm{O} \mathrm{Fp}, 78 \%$ $\mathrm{Mg}_{0.92} \mathrm{Fe}_{0.08} \mathrm{SiO}_{3}$ bridgmanite ( $\mathrm{Bdg}$ ), and $\left.7 \% \mathrm{CaSiO}_{3} \mathrm{CaPv}\right)^{37}$. $\mathrm{Fe}^{2+}{ }_{\mathrm{Fp}}$, NM refers to the $\mathrm{FeO}$ content of $\mathrm{Fp}(18$ mol\%) in the pyrolite model for the normal lower mantle, and the Fe-Mg partition coefficient between $\mathrm{Fp}$ and $\mathrm{Bdg}^{73}$ is used to constrain their $\mathrm{Fe}^{2+}$ contents. The modeled assemblage with different $\mathrm{Fe}^{2+}{ }_{\mathrm{Fp}} / \mathrm{Fe}^{2+} \mathrm{Fp}_{\mathrm{N}} \mathrm{NM}$ ratios has identical mineral fractions to pyrolitic composition in which a portion of $\mathrm{Fe}^{2+}$-bearing $\mathrm{Bdg}$ was substituted by (Mgo..5 $\mathrm{Fe}_{0.5}$ ) $\left(\mathrm{Si}_{0.5} \mathrm{Fe}_{0.5}\right) \mathrm{O}_{3} \mathrm{Bdg}$. Dash green lines represent the $\mathrm{dln} V_{S} / \mathrm{d} \ln V_{P}$ ratio of 2.0 and the light green shadows refer to compositional spaces that can reproduce the large $d \ln V_{S} / d \ln V_{P}$ ratio $>2.0$.

lower mantle by slab/mantle interaction 58,59 , if they reach the lowermost mantle, could be converted back to an oxidized state instead of sinking into the core. Dynamic cycling with respect to mantle redox heterogeneity could provide new insights into the thermochemical evolution of the bulk silicate Earth and possibly the oxidation of the atmosphere.

\section{Methods}

High pressure-temperature experiments. The experiments were conducted using the 1000-ton multi-anvil apparatus at the University of Michigan. The COMPRES $8 / 3$ and $10 / 5$ cell assemblies were employed in the experiments. The starting material was a mixture of high purity $(>99.99 \%) \mathrm{MgO}, \mathrm{SiO}_{2}$, and $\mathrm{Fe}_{2} \mathrm{O}_{3}$ at a molar ratio of 9:9:1, which corresponds to a bulk composition of $\left(\mathrm{Mg}_{0.9} \mathrm{Fe}_{0.1}\right)\left(\mathrm{Si}_{0.9}\right.$ $\left.\mathrm{Fe}_{0.1}\right) \mathrm{O}_{3}$. The mixture was heated at $1073 \mathrm{~K}$ overnight to remove the moisture and structural water before loading into a platinum capsule. The sample was compressed to target pressure and equilibrated at high temperature for 6-10 $\mathrm{h}$ to allow sufficient equilibrium. It was then quenched to room temperature and decompressed to 1 bar.

The recovered sample was polished, coated with carbon, and examined for texture and composition using the JOEL-7800FLV Scanning Electron Microprobe (SEM) and SX-100 Electron Microprobe Analysis (EPMA) at the Electron Microbeam Analysis Laboratory (EMAL) of the University of Michigan. An accelerating voltage of $15 \mathrm{kV}$ and a beam current of $10 \mathrm{nA}$ were employed for imaging and analysis. Forsterite and magnetite were used as standards for $\mathrm{Mg}, \mathrm{Si}$, and Fe quantification with EPMA.

First-principles calculations. Isothermal elastic tensors $\left(C_{i j k l}^{T}\right)$ of crystals in a Cartesian coordinate system usually can be calculated from Eq. (1) (ref. $\left.{ }^{60}\right)$ :

$$
C_{i j k l}^{T}=\frac{1}{V}\left(\frac{\partial^{2} F}{\partial e_{i j} \partial e_{k l}}\right)+\frac{1}{2} P\left(2 \delta_{i j} \delta_{k l}-\delta_{i l} \delta_{k j}-\delta_{i k} \delta_{j l}\right)
$$

where $\mathrm{e}_{i j}(i, j=1,3)$ are infinitesimal strains, $P$ is the isotropic pressure, and $F$ is the Helmholtz free energy, which can be expressed in the quasi-harmonic approximation (QHA) as:

$$
F\left(e_{i j}, V, T\right)=U\left(e_{i j}, V\right)+\frac{1}{2} \sum_{q, m} \hbar \omega_{q, m}\left(e_{i j}, V\right)+k_{B} T \sum_{q, m} \ln \left(1-\exp \left(-\frac{\hbar \omega_{q, m}\left(e_{i j}, V\right)}{k_{B} T}\right)\right)
$$

where $V$ is the equilibrium volume of the crystal and $T$ is temperature. Subscripts $q$ and $m$ refer to the phonon wave vector and the normal mode index, respectively. $\hbar$ and $k_{B}$ are Planck and Boltzmann constants, and $\omega_{q, m}$ is the vibrational frequency of the $i$ th mode along with the wave vector $q$. $U$ is the static energy at the equilibrium volume $V$. The second and third terms are the zero-point and vibrational energy contributions, respectively. Adiabatic elastic constants $\left(C_{i j k l}^{S}\right)$ can be derived from:

$$
C_{i j k l}^{S}=C_{i j k l}^{T}+\frac{T}{V C_{V}} \frac{\partial S}{\partial e_{i j}} \frac{\partial S}{\partial e_{k l}} \delta_{i j} \delta_{k l}
$$

where $S$ is the entropy and $C_{V}$ is the constant volume heat capacity. Therefore, calculations of elastic tensors at high pressure and temperature using this usual method require a vibrational density of states $(\mathrm{VDoS})$ of many strained configurations, which demand a tremendous amount of computational power to calculate based on the DFT. Wu and Wentzcovitch ${ }^{61}$ proposed an analytical approach to calculate the thermal contribution to the elastic tensor, only requiring VDoS for unstrained configurations at different equilibrium volumes. This approach greatly reduces the computation cost to the level of $<10 \%$ of the usual method without loss of accuracy.

To obtain elastic tensors at static conditions and VDoS for unstrained configurations at different equilibrium volumes, we performed first-principles calculations using Quantum Espresso package ${ }^{62}$ based on the DFT, plane wave, and pseudopotential. Local density approximation (LDA) was adopted for the exchange-correlation function. The energy cutoff for electronic wave functions was 



Temperature



Composition

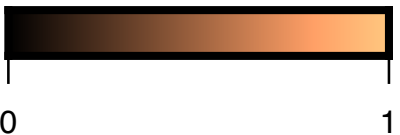

Fig. 5 Formation of thermochemical piles in the lowermost mantle from iron-rich materials. The temperature (left column) and composition (right column) fields from the surface to the core-mantle boundary are shown at $4.5 \mathrm{Gyr}$ for case 1 (a, b), case 2 (c, d), case 3 (e, f), and case 4 ( $\mathbf{g}, \mathbf{h})$. In cases 1 , 2,3 , and 4 , the Rayleigh number is $R a=1 \times 10^{7}, 1 \times 10^{6}, 1 \times 10^{8}$, and $1 \times 10^{7}$, respectively, and the iron-rich materials (shown by golden colors in the right panels) are $1.2 \%, 1.2 \%, 1.2 \%$, and $1.5 \%$ intrinsically denser than the background mantle materials (shown by black colors in the right panels), respectively. Large thermochemical piles form after 4.5 Gyr for all cases.

set as $70 \mathrm{Ry}$. The $\mathrm{Mg}$ pseudopotential was generated using the von Barth and Car method for all channels using a $2.5 \mathrm{Bohr}$ cutoff radius and five configurations, $3 \mathrm{~s}^{2} 3 \mathrm{p}^{0}, 3 \mathrm{~s}^{1} 3 \mathrm{p}^{1}, 3 \mathrm{~s}^{1} 3 \mathrm{p}^{0.5} 3 \mathrm{~d}^{0.5}, 3 \mathrm{~s}^{1} 3 \mathrm{p}^{0.5}, 3 \mathrm{~s}^{1} 3 \mathrm{~d}^{1}$, with weights of $1.5,0.6,0.3,0.3,0.2$, respectively. The pseudopotentials for $\mathrm{Si}$ and $\mathrm{O}$ were generated using the TroullierMartins method ${ }^{63}$ with the cutoff radius of $1.47 \mathrm{Bohr}$ for $\mathrm{Si}$ and 1.45 Bohr for O. Valence configurations for $\mathrm{Si}$ and $\mathrm{O}$ are $3 \mathrm{~s}^{2} 3 \mathrm{p}^{4} 3 \mathrm{~d}^{0}$ and $2 \mathrm{~s}^{2} 2 \mathrm{p}^{4}$, respectively. The pseudopotentials for $\mathrm{Al}$ and Fe were generated using the Vanderbilt method ${ }^{64}$ with a valence configuration of $3 \mathrm{~s}^{2} 3 \mathrm{p}^{1}$ and a cutoff radius of $1.77 \mathrm{Bohr}$ for $\mathrm{Al}$, and a valence configuration of $3 \mathrm{~s}^{2} 3 \mathrm{p}^{6} 3 \mathrm{~d}^{6.5} 4 \mathrm{~s}^{1} 4 \mathrm{p}^{0}$ and a cutoff radius of $1.8 \mathrm{Bohr}$ for Fe. To address the large on-site Coulomb interactions among the localized electrons (Fe $3 \mathrm{~d}$ electrons) ${ }^{65}$, we introduced a Hubbard $U$ correction to the LDA $(\mathrm{LDA}+U$ ) for all DFT calculations. $U$ values for $\mathrm{Fe}^{3+}$ on A and B sites in bridgmanite were non-empirically determined using linear response method ${ }^{66}$ in previous work ${ }^{43}$ and adopted in this study. The initial structure was constructed by replacing one nearest-neighbor $\mathrm{Mg}^{2+}-\mathrm{Si}^{4+}$ pair with one $\left[\mathrm{Fe}^{3+}\right]_{\mathrm{Mg}^{-}}\left[\mathrm{Fe}^{3+}\right]^{\mathrm{Si}}$ pair ${ }^{43-45}$. Crystal structures at variable pressures were well optimized on a $6 \times 6 \times 4 \mathrm{k}$-point mesh, and VDoS were calculated using the finite displacement method as implemented in the code PHONOPY ${ }^{67}$. The elastic tensors at static conditions were calculated from the linear dependence of stress on the small strain. Owing to the enormous computational cost of calculating the vibrational density of state based on LDA $+U$, we used the 20 -atom unit cell for $\left(\mathrm{Mg}_{0.5} \mathrm{Fe}_{0.5}\right)\left(\mathrm{Si}_{0.5} \mathrm{Fe}_{0.5}\right) \mathrm{O}_{3}$ bridgmanite ${ }^{43-45}$ Similar to previous studies on the elastic properties of Fe-bearing bridgmanite ${ }^{45,46}$, we only report results for aggregate elastic moduli, not individual elastic coefficients. The latter are sensitive to atomic configurations and therefore to supercell size, which can accommodate different configurations for the same composition. The aggregate elastic moduli, $K_{S}$ and $G$, are quite insensitive to the atomic configuration ${ }^{68-70}$

The Helmholtz free energy calculated from Eq. (2) within the QHA versus volume was fitted by the isothermal third-order finite strain equation of state, and then we can obtain all thermodynamic properties, such as pressures at different temperatures and volumes. Our results show that $\left(\mathrm{Mg}_{0.5} \mathrm{Fe}_{0.5}\right)\left(\mathrm{Si}_{0.5} \mathrm{Fe}_{0.5}\right) \mathrm{O}_{3}$ bridgmanite has a larger volume than $\left(\mathrm{Mg}_{0.5} \mathrm{Fe}_{0.5}\right)\left(\mathrm{Si}_{0.5} \mathrm{Al}_{0.5}\right) \mathrm{O}_{3}$ bridgmanite (Fig. 2). The substitution of $\mathrm{Al}^{3+}$ for $\mathrm{LS} \mathrm{Fe}^{3+}$ in the octahedral site causes a slight decrease of $\sim 1.0 \%$ in volume at $>80 \mathrm{GPa}$. Compared to pristine $\mathrm{Bdg}\left(\mathrm{MgSiO}_{3}\right)$, these two $\mathrm{Fe}^{3+}$ - and $\mathrm{Al}^{3+}$-rich species have larger volumes; for example, at $90 \mathrm{GPa}$ and $2000 \mathrm{~K}$, the volumes of $\left(\mathrm{Mg}_{05} \mathrm{Fe}_{0.5}\right)\left(\mathrm{Si}_{05} \mathrm{Al}_{0.5}\right) \mathrm{O}_{3}$ and $\left(\mathrm{Mg}_{0.5} \mathrm{Fe}_{0.5}\right)\left(\mathrm{Si}_{05} \mathrm{Fe}_{0.5}\right) \mathrm{O}_{3}$ are $3.5 \%$ and $4.4 \%$ larger than that of $\mathrm{MgSiO}_{3}$, respectively.

Using the equation of states, we transferred volume- and temperaturedependent elasticity into pressure- and temperature-dependent elasticity. The adiabatic bulk modulus $K_{S}$ and shear modulus $G$ can be obtained by computing the Voigt-Reuss-Hill averages ${ }^{71}$ from elastic tensors. Thus, compressional and shear velocities can be calculated from the equations $V_{P}=\sqrt{\left(K s+\frac{4}{3} G\right) / \rho}$ and $V_{S}=$ $\sqrt{G / \rho}\left(\rho\right.$ is density). Bulk moduli $\left(K_{S}\right)$, shear moduli $(G)$, compressional-wave velocity $\left(V_{P}\right)$, and shear-wave velocity $\left(V_{S}\right)$ are also derived from $L D A+U$ calculations as shown in Supplementary Fig. 3. Compared to $\left(\mathrm{Mg}_{0.5} \mathrm{Fe}_{0.5}\right)\left(\mathrm{Si}_{0.5} \mathrm{Fe}_{0.5}\right)$ $\mathrm{O}_{3} \mathrm{Bdg},\left(\mathrm{Mg}_{0.5} \mathrm{Fe}_{0.5}\right)\left(\mathrm{Si}_{0.5} \mathrm{Al}_{0.5}\right) \mathrm{O}_{3}$ Bdg has a lower density, similar $K_{S}$ but much larger $G$ at $>90 \mathrm{GPa}$, which results in much higher velocities in $\left(\mathrm{Mg}_{0.5} \mathrm{Fe}_{0.5}\right)$ $\left(\mathrm{Si}_{0.5} \mathrm{Al}_{0.5}\right) \mathrm{O}_{3}$ Bdg. At $100 \mathrm{GPa}$ and $2000 \mathrm{~K}$, the differences in density, $K_{S}, G, V_{P}$, and $V_{S}$ between $\left(\mathrm{Mg}_{0.5} \mathrm{Fe}_{0.5}\right)\left(\mathrm{Si}_{0.5} \mathrm{Al}_{0.5}\right) \mathrm{O}_{3}$ and $\left(\mathrm{Mg}_{0.5} \mathrm{Fe}_{0.5}\right)\left(\mathrm{Si}_{0.5} \mathrm{Fe}_{0.5}\right) \mathrm{O}_{3}$ are $-10.4 \%,-0.9 \%, 19.2 \%, 8.1 \%$, and $14.8 \%$, respectively. Elastic moduli and velocities almost linearly depend on pressure and temperature after $\mathrm{B}$-site $\mathrm{Fe}^{3+}$ spin transition and their first pressure and temperature derivatives are comparable to those of $\mathrm{MgSiO}_{3} \mathrm{Bdg}$ (Supplementary Table 3).

Ab initio investigation on the stability of $\left(\mathrm{Mg}_{0.5} \mathrm{Fe}_{0.5}\right)\left(\mathrm{Si}_{0.5} \mathrm{Fe}_{0.5}\right) \mathrm{O}_{3}$ bridgmanite. Through high-pressure and high-temperature experiments, we find the formation of iron-rich bridgmanite $\left(\mathrm{Mg}_{0.5} \mathrm{Fe}_{0.5}\right)\left(\mathrm{Si}_{0.5} \mathrm{Fe}_{0.5}\right) \mathrm{O}_{3}$ coexisting with $\mathrm{Fe}$ poor bridgmanite, instead of forming a single phase of $\left(\mathrm{Mg}_{0.9} \mathrm{Fe}_{0.1}\right)\left(\mathrm{Si}_{0.9} \mathrm{Fe}_{0.1}\right) \mathrm{O}_{3}$ Bdg with homogeneous iron content. In order to check the relative stability of $\left(\mathrm{Mg}_{0.5} \mathrm{Fe}_{0.5}\right)\left(\mathrm{Si}_{0.5} \mathrm{Fe}_{0.5}\right) \mathrm{O}_{3}$ bridgmanite, we also calculated the formation energy of the decomposition reaction:

$\left(\mathrm{Mg}_{0.875} \mathrm{Fe}_{0.125}\right)\left(\mathrm{Si}_{0.875} \mathrm{Fe}_{0.125}\right) \mathrm{O}_{3} \leftrightarrow 3 / 4 \mathrm{MgSiO}_{3}+1 / 4\left(\mathrm{Mg}_{0.5} \mathrm{Fe}_{0.5}\right)\left(\mathrm{Si}_{0.5} \mathrm{Fe}_{0.5}\right)$

The Gibbs free energy of $\left(\mathrm{Mg}_{1-\mathrm{x}} \mathrm{Fe}_{\mathrm{x}}\right)\left(\mathrm{Si}_{1-\mathrm{x}} \mathrm{Fe}_{\mathrm{x}}\right) \mathrm{O}_{3}$ can be expressed as (see Supplementary Materials):

$$
G_{\mathrm{HS} / \mathrm{LS}}(P, T)=G_{\mathrm{HS} / \mathrm{ls}}^{\mathrm{sta}+\mathrm{vib}}(P, T)+G_{\mathrm{HS} / \mathrm{LS}}^{\mathrm{mag}}(P, T)-\mathrm{TS}^{\text {conf }}
$$

where $S^{\text {conf }}$ is the configurational entropy $\left(S^{\text {conf }}=k_{B} \ln M, M\right.$ is the configuration degeneracy). $G_{\mathrm{HS} / \mathrm{s}}^{\mathrm{stat}}(P, T)$ and $G_{\mathrm{HS} / \mathrm{LS}}^{\mathrm{mag}}(P, T)$ can be derived from 
Eqs. (3-6) in Supplementary Materials. Thus, the Gibbs formation free energy of the decomposition reaction for pure HS/LS state can be expressed as:

$$
\Delta G=\frac{1}{4} *\left(G_{x=0.5}^{\mathrm{sta}+\mathrm{vib}}-\mathrm{TS}_{x=0.5}^{\mathrm{conf}}\right)+\frac{3}{4} * G_{\mathrm{MgSiO} 3}^{\mathrm{stat}+\mathrm{vib}}-\left(G_{x=0.125}^{\mathrm{sta}+\mathrm{vib}}-\mathrm{TS}_{x=0.125}^{\mathrm{conf}}\right)
$$

We also investigated the disordered substitution of $\mathrm{Fe}^{3+}$ in $\left(\mathrm{Mg}_{0.875} \mathrm{Fe}_{0.125}\right)$ $\left(\mathrm{Si}_{0.875} \mathrm{Fe}_{0.125}\right) \mathrm{O}_{3}$ bridgmanite in a 40 -atom cell $(\sqrt{2} \times \sqrt{2} \times 1$ supercell). Similar to the case for $\left(\mathrm{Mg}_{0.5} \mathrm{Fe}_{0.5}\right)\left(\mathrm{Si}_{0.5} \mathrm{Fe}_{0.5}\right) \mathrm{O}_{3}$ bridgmanite, the initial structure was constructed by replacing one nearest-neighbor $\mathrm{Mg}^{2+}-\mathrm{Si}^{4+}$ pair with one $\left[\mathrm{Fe}^{3+}\right]_{\mathrm{Mg}}-$ $\left[\mathrm{Fe}^{3+}\right]^{\mathrm{Si}}$ pair. Due to the extremely high computational cost of VDOS calculation using $\mathrm{LDA}+U$ functional, we did not calculate the VDOS of $\left(\mathrm{Mg}_{0.875} \mathrm{Fe}_{0.125}\right)$ $\left(\mathrm{Si}_{0.875} \mathrm{Fe}_{0.125}\right) \mathrm{O}_{3}$ bridgmanite. Because $\left(\mathrm{Mg}_{1-\mathrm{x}} \mathrm{Fe}_{\mathrm{x}}\right)\left(\mathrm{Si}_{1-\mathrm{x}} \mathrm{Fe}_{\mathrm{x}}\right) \mathrm{O}_{3}$ bridgmanite with different $\mathrm{Fe}^{3+}$ contents have similar structures, here we assume that the vibrational contribution to the Gibbs free energy linearly depends on $\mathrm{Fe}^{3+}$ content $\left(G_{x=0.125}^{\mathrm{vib}}=\frac{1}{4} * G_{x=0.5}^{\mathrm{vib}}+\frac{3}{4} * G_{\mathrm{MgSiO} 3}^{\mathrm{vib}}\right)$. Under this approximation, $\Delta G$ can be written as:

$$
\Delta G=\frac{1}{4} *\left(H_{x=0.5}^{\mathrm{stat}}-\mathrm{TS}_{x=0.5}^{\mathrm{conf}}\right)+\frac{3}{4} * H_{\mathrm{MgSiO} 3}^{\mathrm{stat}}-\left(H_{x=0.125}^{\mathrm{stat}}-\mathrm{TS}_{x=0.125}^{\mathrm{conf}}\right)
$$

where $H^{\text {stat }}$ is the internal energy or the Gibbs free energy without the vibrational contribution.

As shown in Supplementary Fig. 2, $\Delta \mathrm{G}$ is negative at lower-mantle conditions regardless of the spin state of $\mathrm{B}$-site $\mathrm{Fe}^{3+}$ in $\left(\mathrm{Mg}_{1-\mathrm{x}} \mathrm{Fe}_{\mathrm{x}}\right)\left(\mathrm{Si}_{1-\mathrm{x}} \mathrm{Fe}_{\mathrm{x}}\right) \mathrm{O}_{3}$ bridgmanite. This implies that the assemblage of $\left(\mathrm{Mg}_{0.5} \mathrm{Fe}_{0.5}\right)\left(\mathrm{Si}_{0.5} \mathrm{Fe}_{0.5}\right) \mathrm{O}_{3}$ and $\mathrm{MgSiO}_{3}$ bridgmanite is more stable than the single-phase $\left(\mathrm{Mg}_{0.875} \mathrm{Fe}_{0.125}\right)\left(\mathrm{Si}_{0.875} \mathrm{Fe}_{0.125}\right) \mathrm{O}_{3}$ bridgmanite, consistent with our experimental results (Fig. 1). In addition, our $\mathrm{LDA}+U$ calculations extend the occurrence of this decomposition reaction to the lowermost-mantle conditions, where $\left(\mathrm{Mg}_{0.5} \mathrm{Fe}_{0.5}\right)\left(\mathrm{Si}_{0.5} \mathrm{Fe}_{0.5}\right) \mathrm{O}_{3}$ bridgmanite is still more stable than $\left(\mathrm{Mg}_{0.875} \mathrm{Fe}_{0.125}\right)\left(\mathrm{Si}_{0.875} \mathrm{Fe}_{0.125}\right) \mathrm{O}_{3}$ bridgmanite.

In order to check the effect of the exchange-correlation function on the results, we also calculated the enthalpy change of this reaction using the generalized gradient approximation with Hubbard $U$ correction $\left(\mathrm{GGA}+U\right.$ ). $U$ values for $\mathrm{Fe}^{3+}$ on $\mathrm{A}$ and $\mathrm{B}$ sites in bridgmanite are 3.3 and $4.5 \mathrm{eV}$, respectively. The $\Delta H$ predicted by the GGA $+U$ calculations is similar to that from the $L D A+U$ calculations (Supplementary Fig. 2), both of which favor the mixed phases over the single phase.

\section{Thermoelastic models for the estimations of velocity and density hetero-}

geneities. Previous studies ${ }^{37}$ have suggested that the pyrolitic lower mantle that consists of $15 \% \mathrm{Mg}_{0.82} \mathrm{Fe}_{0.18} \mathrm{O}$ ferropericlase (Fp), $78 \% \mathrm{Mg}_{0.92} \mathrm{Fe}_{0.08} \mathrm{SiO}_{3}$ bridgmanite $\left(\mathrm{Fe}^{2+}\right.$ - $\left.\mathrm{Bdg}\right)$, and $7 \% \mathrm{CaSiO}_{3}$ Ca-perovskite $\left.(\mathrm{CaPv})\right)$ can admirably reproduce the velocity and density profiles of PREM model ${ }^{72}$ for the lower mantle. Combining the thermoelastic properties ${ }^{20,46,47}$ of these three major minerals with our elastic data for LS- $\left(\mathrm{Mg}_{0.5} \mathrm{Fe}_{0.5}\right)\left(\mathrm{Si}_{0.5} \mathrm{Fe}_{0.5}\right) \mathrm{O}_{3}$ and $\left(\mathrm{Mg}_{0.5} \mathrm{Fe}_{0.5}\right)\left(\mathrm{Si}_{0.5} \mathrm{Al}_{0.5}\right) \mathrm{O}_{3}$ bridgmanite, we quantify the dependences of velocity and density anomalies on the amount of $\mathrm{Fe}^{3+}$-rich Bdg by substituting a certain proportion of $\mathrm{Fe}^{3+}$-free $\mathrm{Bdg}$ with $\left(\mathrm{Mg}_{0.5} \mathrm{Fe}_{0.5}\right)\left(\mathrm{Si}_{0.5} \mathrm{Fe}_{0.5}\right) \mathrm{O}_{3}$ bridgmanite. Compared to the pyrolitic composition, the modeling chemical assemblage has identical mineral fractions $(15 \%$ fer ropericlase $+78 \% \mathrm{Bdg}+7 \% \mathrm{CaPv}$ ) in which a portion of $\mathrm{Fe}^{2+}$-bearing $\mathrm{Bdg}$ was substituted by $\left(\mathrm{Mg}_{0.5} \mathrm{Fe}_{0.5}\right)\left(\mathrm{Si}_{0.5} \mathrm{Fe}_{0.5}\right) \mathrm{O}_{3}$ or $\left(\mathrm{Mg}_{0.5} \mathrm{Fe}_{0.5}\right)\left(\mathrm{Si}_{0.5} \mathrm{Fe}_{0.4} \mathrm{Al}_{0.1}\right) \mathrm{O}_{3}$ Bdg. In other words, the ferropericlase and Ca-perovskite contents are fixed to $15 \%$ and $7 \%$, respectively. We also explore the effect of $\mathrm{Fe}^{2+}$ content in the assemblage (noted by the $\mathrm{Fe}^{2+}$ content in $\mathrm{Fp}, \mathrm{Fe}^{2+}{ }_{\mathrm{Fp}}$ ) on modeling results because the incorporation of $\mathrm{Fe}^{2+}$ into $\mathrm{Fp}$ and Bdg decreases their velocities to some extent ${ }^{46,47}$. The $\mathrm{Fe}-\mathrm{Mg}$ partition coefficient between $\mathrm{Fp}$ and $\mathrm{Bdg}^{73}$ is used to constrain their $\mathrm{Fe}^{2+}$ contents. The modeled aggregate with enrichment of $\mathrm{Fe}^{3+}$-rich $\mathrm{Bdg}$ is composed of $15 \% \mathrm{Mg}_{1-\mathrm{x}} \mathrm{Fe}_{\mathrm{x}} \mathrm{O}$ ferropericlase, $7 \% \mathrm{CaSiO}_{3} \mathrm{Ca}$-perovskite, $\mathrm{Z} \%\left(\mathrm{Mg}_{0.5} \mathrm{Fe}_{0.5}\right)\left(\mathrm{Si}_{0.5} \mathrm{Fe}_{0.5}\right) \mathrm{O}_{3}$ or $\left(\mathrm{Mg}_{0.5} \mathrm{Fe}_{0.5}\right)\left(\mathrm{Si}_{0.5} \mathrm{Fe}_{0.4} \mathrm{Al}_{0.1}\right) \mathrm{O}_{3}$ bridgmanite, and $(78-\mathrm{Z}) \% \mathrm{Mg}_{1-\mathrm{y}} \mathrm{Fe}_{\mathrm{y}} \mathrm{SiO}_{3}$ bridgmanite.

The elastic moduli and densities of the aggregate are calculated using:

$$
\begin{gathered}
\rho=\sum_{i} f_{i} \rho_{i} \\
M=\frac{1}{2}\left[\sum_{i} f_{i} M_{i}+\left(\sum_{i} f_{i} M_{i}^{-1}\right)^{-1}\right]
\end{gathered}
$$

where $\rho_{\mathrm{i}}, M_{i}$, and $f_{i}$ are the density, bulk modulus $\left(K_{S}\right)$ or shear modulus $(G)$, and the fraction of the $i$ th mineral, respectively. Similarly, the compressional and shear velocities $\left(V_{P}\right.$ and $\left.V_{S}\right)$ were derived from $V_{P}=\sqrt{\left(K s+\frac{4}{3} G\right) / \rho}$ and $V_{S}=\sqrt{G / \rho}$, and hence the velocity and density anomalies relative to the pyrolitic lower mantle are estimated with the consideration of temperature anomaly.

Geodynamic models. We performed thermochemical calculations to study the dynamics of iron-rich materials in the lowermost mantle. The numerical simulations were conducted by solving the nondimensional equations of conservation of mass, momentum, and energy under the Boussinesq approximation. The intrinsic density anomaly is represented by the buoyancy number $B$, which is defined as the ratio between the intrinsic (compositional) density anomaly and the density anomaly caused by thermal expansion, $B=\Delta \rho /(\rho \alpha \Delta T)$, where $\Delta \rho$ is the intrinsic density anomaly for the iron-rich materials compared to the background mantle. We used $\alpha=1 \times 10^{-5} \mathrm{~K}^{-1}$ and $\Delta T=2500 \mathrm{~K}$ in this study.
The whole-mantle dynamics is simulated in a 2D Cartesian box with an aspect ratio of 3:1. The model domain contains 1536 and 512 elements in the horizontal and vertical directions, respectively. Models are basally heated, with the top and bottom having a fixed temperature at $T=0$ and $T=1$, respectively. The top and bottom boundaries are both free-flip and the side boundaries are reflective. The viscosity is determined by $\eta=\eta_{0} \exp [0.5-T]$, where $\eta_{0}$ is a viscosity pre-factor, and $A$ is the activation energy. Here, $\eta_{0}$ is 1.0 and 30.0 for the upper mantle and the lower mantle, respectively, and $A=9.21$ which leads to the viscosity changing four orders of magnitude as temperature increases from 0 to 1 . Initially, the whole mantle was assumed to be hot with a temperature of $T=0.72$ (or $1800 \mathrm{~K}$ ) everywhere, and we introduced a global layer of iron-rich materials in the lowermost $300 \mathrm{~km}$ of the mantle.

We performed four cases. Case 1 is the reference case in which the iron-rich materials are $1.2 \%$ intrinsically denser (with a buoyancy number of $B=0.48$ ) than the background mantle materials and the Rayleigh number, which controls the vigor of mantle convection, is $R a=1 \times 10^{7}$. Cases 2 and 3 have a Rayleigh number of $R a=1 \times 10^{6}$ and $R a=1 \times 10^{8}$, respectively, while other parameters are the same as case 1 . In case 4 , the iron-rich materials are $1.5 \%$ intrinsically denser (with a buoyancy number of $B=0.6$ ) than the background mantle materials, and other parameters are the same as case 1 .

\section{Data availability}

The data are available in the main text, the supplementary materials, and from the corresponding authors.

\section{Code availability}

The open-source Quantum Espresso package used in this study is available at https://www.quantum-espresso.org/.

Received: 10 July 2020; Accepted: 26 February 2021; Published online: 26 March 2021

\section{References}

1. Ni, S. Sharp Sides to the African Superplume. Science 296, 1850-1852 (2002). 2. Ritsema, J., Ni, S., Helmberger, D. V. \& Crotwell, H. P. Evidence for strong shear velocity reductions and velocity gradients in the lower mantle beneath Africa. Geophys. Res. Lett. 25, 4245-4248 (1998).

3. Wang, Y. \& Wen, L. Mapping the geometry and geographic distribution of a very low velocity province at the base of the Earth's mantle. J. Geophys. Res. Solid Earth 109, 1-18 (2004).

4. Cottaar, S. \& Lekic, V. Morphology of seismically slow lower-mantle structures. Geophys. J. Int. 207, 1122-1136 (2016).

5. McNamara, A. K. A review of large low shear velocity provinces and ultra low velocity zones. Tectonophysics $0-1$. https://doi.org/10.1016/j.tecto.2018.04.015 (2018).

6. Garnero, E. J., McNamara, A. K. \& Shim, S. H. Continent-sized anomalous zones with low seismic velocity at the base of Earth's mantle. Nat. Geosci. 9, 481-489 (2016).

7. Huang, C., Leng, W., \& Wu, Z. Iron-spin transition controls structure and stability of LLSVPs in the lower mantle. Earth Planet. Sci. Lett. 423, 173-181 (2015).

8. Frost, D. A. \& Rost, S. The P-wave boundary of the Large-Low Shear Velocity Province beneath the Pacific. Earth Planet. Sci. Lett. 403, 380-392 (2014).

9. Wang, Y. \& Wen, L. Geometry and P and S velocity structure of the 'African Anomaly'. J. Geophys. Res. Solid Earth 112, 1-26 (2007).

10. Sun, D., Helmberger, D., Ni, S. \& Bower, D. Direct measures of lateral velocity variation in the deep Earth. J. Geophys. Res. Solid Earth 114, 1-18 (2009).

11. Wen, L., Silver, P., James, D. \& Kuehnel, R. Seismic evidence for a thermochemical boundary at the base of the Earth's mantle. Earth Planet. Sci. Lett. 189, 141-153 (2001).

12. Ritsema, J., Garnero, E. \& Lay, T. A strongly negative shear velocity gradient and lateral variability in the lowermost mantle beneath the Pacific. J. Geophys. Res. Earth 102, 20395-20411 (1997).

13. Trampert, J., Deschamps, F., Resovsky, J. \& Yuen, D. Probabilistic tomography maps chemical heterogeneities throughout the lower mantle. Science 306, 853-856 (2004).

14. Lau, H. C. P. et al. Tidal tomography constrains Earth's deep-mantle buoyancy. Nature 551, 321-326 (2017).

15. Koelemeijer, P., Deuss, A. \& Ritsema, J. Density structure of Earth's lowermost mantle from Stoneley mode splitting observations. Nat. Commun. 8, 1-10 (2017).

16. Christensen, U. R. \& Hofmann, A. W. Segregation of subducted oceanic crust in the convecting mantle. J. Geophys. Res. Solid Earth 99, 19867-19884 (1994). 
17. Ricolleau, A. et al. Phase relations and equation of state of a natural MORB: Implications for the density profile of subducted oceanic crust in the Earth's lower mantle. J. Geophys. Res. 115, B08202 (2010).

18. Thomson, A. R. et al. Seismic velocities of $\mathrm{CaSiO}_{3}$ perovskite can explain LLSVPs in Earth's lower mantle. Nature 572, 643-647 (2019).

19. Gréaux, $\mathrm{S}$. et al. Sound velocity of $\mathrm{CaSiO}_{3}$ perovskite suggests the presence of basaltic crust in the Earth's lower mantle. Nature 565, 218-221 (2019).

20. Kawai, K. \& Tsuchiya, T. Small shear modulus of cubic $\mathrm{CaSiO}_{3}$ perovskite. Geophys. Res. Lett. 42, 2718-2726 (2015)

21. Wang, W. et al. Velocity and density characteristics of subducted oceanic crust and the origin of lower-mantle heterogeneities. Nat. Commun. 11, 64 (2020).

22. Li, M. \& McNamara, A. K. The difficulty for subducted oceanic crust to accumulate at the Earth's core-mantle boundary. J. Geophys. Res. Solid Earth 118, 1807-1816 (2013).

23. McNamara, A. K. \& Zhong, S. Thermochemical structures beneath Africa and the Pacific Ocean. Nature 437, 1136-1139 (2005)

24. Lee, C. T. A. et al. Upside-down differentiation and generation of a primordial lower mantle. Nature 463, 930-933 (2010).

25. Labrosse, S., Hernlund, J. W. \& Coltice, N. A crystallizing dense magma ocean at the base of the Earth's mantle. Nature 450, 866-869 (2007).

26. Nomura, R. et al. Spin crossover and iron-rich silicate melt in the Earth's deep mantle. Nature 473, 199-202 (2011).

27. Tackley, P. J. Mantle geochemical geodynamics. In Treatise on Geophysics Vol. 7, (ed. G. Schubert) 521-585 (Elsevier, 2015).

28. Zhang, Z. et al. Primordial metallic melt in the deep mantle. Geophys. Res. Lett. 43, 3693-3699 (2016)

29. Shi, C. Y. et al. Formation of an interconnected network of iron melt at Earth's lower mantle conditions. Nat. Geosci. 6, 971-975 (2013).

30. Armstrong, K., Frost, D. J., McCammon, C. A., Rubie, D. C. \& Boffa Ballaran, T. Deep magma ocean formation set the oxidation state of Earth's mantle. Science 365, 903-906 (2019).

31. Frost, D. J. et al. Experimental evidence for the existence of iron-rich metal in the Earth's lower mantle. Nature 428, 409-412 (2004).

32. Shim, S.-H. et al. Stability of ferrous-iron-rich bridgmanite under reducing midmantle conditions. Proc. Natl Acad. Sci. USA 114, 6468-6473 (2017).

33. Bindi, L., Shim, S.-H., Sharp, T. G. \& Xie, X. Evidence for the charge disproportionation of iron in extraterrestrial bridgmanite. Sci. Adv. 6, eaay7893 (2020)

34. Andrault, D. et al. Large oxygen excess in the primitive mantle could be the source of the great oxygenation event. Geochem. Perspect. Lett. 5-10. https:// doi.org/10.7185/geochemlet.1801 (2018).

35. Liu, J., Mysen, B., Fei, Y. \& Li, J. Recoil-free fractions of iron in aluminous bridgmanite from temperature-dependent Mössbauer spectra. Am. Mineral. 100, 1978-1984 (2015)

36. Liu, J. et al. Valence and spin states of iron are invisible in Earth's lower mantle. Nat. Commun. 9, 1-9 (2018).

37. $\mathrm{Wu}, \mathrm{Z}$. Velocity structure and composition of the lower mantle with spin crossover in ferropericlase. J. Geophys. Res. Solid Earth 121, 2304-2314 (2016).

38. Wang, X., Tsuchiya, T. \& Hase, A. Computational support for a pyrolitic lower mantle containing ferric iron. Nat. Geosci. 8, 556-559 (2015).

39. Hummer, D. R. \& Fei, Y. Synthesis and crystal chemistry of $\mathrm{Fe}^{3+}$-bearing $(\mathrm{Mg}$, $\left.\mathrm{Fe}^{3+}\right)\left(\mathrm{Si}_{3} \mathrm{Fe}^{3+}\right) \mathrm{O}_{3}$ perovskite. Am. Mineral. 97, 1915-1921 (2012).

40. Catalli, K. et al. Spin state of ferric iron in $\mathrm{MgSiO}_{3}$ perovskite and its effect on elastic properties. Earth Planet. Sci. Lett. 289, 68-75 (2010).

41. Tateno, S., Hirose, K., Ohishi, Y. \& Tatsumi, Y. The structure of iron in Earth's inner core. Science 330, 359-361 (2010).

42. Zhu, F. et al. Synthesis, elasticity, and spin state of an intermediate $\mathrm{MgSiO}_{3}-\mathrm{FeAlO}_{3}$ bridgmanite: implications for iron in Earth's lower mantle. J. Geophys. Res. Solid Earth 125, 1-11 (2020).

43. Hsu, H., Blaha, P., Cococcioni, M. \& Wentzcovitch, R. M. Spin-state crossover and hyperfine interactions of ferric iron in $\mathrm{MgSiO}_{3}$ perovskite. Phys. Rev. Lett. 106, 118501 (2011).

44. Shukla, G. \& Wentzcovitch, R. M. Spin crossover in $\left(\mathrm{Mg}, \mathrm{Fe}^{3+}\right)\left(\mathrm{Si}_{1}, \mathrm{Fe}^{3+}\right) \mathrm{O}_{3}$ bridgmanite: effects of disorder, iron concentration, and temperature. Phys. Earth Planet. Inter. 260, 53-61 (2016).

45. Shukla, G., Cococcioni, M. \& Wentzcovitch, R. M. Thermoelasticity of $\mathrm{Fe}^{3+}$ and Al-bearing bridgmanite. Geophys. Res. Lett. https://doi.org/10.1002/ 2016GL069332 (2016).

46. Shukla, G. et al. Thermoelasticity of $\mathrm{Fe}^{2+}$-bearing bridgmanite. Geophys. Res. Lett. 42, 1741-1749 (2015)

47. Wu, Z., Justo, J. F. \& Wentzcovitch, R. M. Elastic anomalies in a spincrossover system: ferropericlase at lower mantle conditions. Phys. Rev. Lett. 110, 228501 (2013).

48. Wang, W. \& Wu, Z. Elasticity of corundum at high pressures and temperatures: implications for pyrope decomposition and Al-content effect on elastic properties of bridgmanite. J. Geophys. Res. Solid Earth 123, 1201-1216 (2018)
49. Romanowicz, B. The buoyancy of Earth's deep mantle. Nature 551, 308-309 (2017).

50. Tan, E. Metastable superplumes and mantle compressibility. Geophys. Res. Lett. 32, L20307 (2005).

51. Li, M., Zhong, S. \& Olson, P. Linking lowermost mantle structure, core-mantle boundary heat flux and mantle plume formation. Phys. Earth Planet. Inter. 277, 10-29 (2018).

52. Li, M., McNamara, A. K. \& Garnero, E. J. Chemical complexity of hotspots caused by cycling oceanic crust through mantle reservoirs. Nat. Geosci. 7, 366-370 (2014)

53. Boukaré, C.-E., Ricard, Y. \& Fiquet, G. Thermodynamics of the MgO-FeO$\mathrm{SiO}_{2}$ system up to $140 \mathrm{GPa}$ : Application to the crystallization of Earth's magma ocean. J. Geophys. Res. Solid Earth 120, 6085-6101 (2015).

54. Frost, D. J. \& McCammon, C. A. The redox state of Earth's mantle. Annu. Rev. Earth Planet. Sci. 36, 389-420 (2008).

55. Gu, T., Li, M., McCammon, C. \& Lee, K. K. M. Redox-induced lower mantle density contrast and effect on mantle structure and primitive oxygen. Nat. Geosci. 9, 723-727 (2016)

56. Dauphas, N. et al. Magma redox and structural controls on iron isotope variations in Earth's mantle and crust. Earth Planet. Sci. Lett. 398, 127-140 (2014).

57. Liu, J. et al. Iron isotopic fractionation between silicate mantle and metallic core at high pressure. Nat. Commun. 8, ncomms14377 (2017).

58. Smith, E. M. et al. Large gem diamonds from metallic liquid in Earth's deep mantle. Science 354, 1403-1405 (2016).

59. Liu, J., Li, J., Hrubiak, R. \& Smith, J. S. Origins of ultralow velocity zones through slab-derived metallic melt. Proc. Natl Acad. Sci. USA 113, 5547-5551 (2016).

60. Barron, T. H. K. \& Klein, M. L. Second-order elastic constants of a solid under stress. Proc. Phys. Soc. 85, 523-532 (1965).

61. Wu, Z. \& Wentzcovitch, R. M. Quasiharmonic thermal elasticity of crystals: an analytical approach. Phys. Rev. B 83, 184115 (2011).

62. Giannozzi, P. et al. QUANTUM ESPRESSO: a modular and open-source software project for quantum simulations of materials. J. Phys. Condens. Matter 21, 395502 (2009).

63. Troullier, N. \& Martins, J. L. Efficient pseudopotentials for plane-wave calculations. II. Operators for fast iterative diagonalization. Phys. Rev. B 43, 8861-8869 (1991)

64. Vanderbilt, D. Soft self-consistent pseudopotentials in a generalized eigenvalue formalism. Phys. Rev. B 41, $7892-7895$ (1990).

65. Anisimov, V. I., Zaanen, J. \& Andersen, O. K. Band theory and Mott insulators: Hubbard U instead of Stoner I. Phys. Rev. B 44, 943-954 (1991).

66. Cococcioni, M. \& de Gironcoli, S. Linear response approach to the calculation of the effective interaction parameters in the LDA+U method. Phys. Rev. B 71, 035105 (2005).

67. Togo, A. \& Tanaka, I. First principles phonon calculations in materials science. Scr. Mater. 108, 1-5 (2015).

68. Núñez Valdez, M., Wu, Z., Yu, Y. G., Revenaugh, J. \& Wentzcovitch, R. M. Thermoelastic properties of ringwoodite $\left(\mathrm{Fex}, \mathrm{Mg}_{1-\mathrm{x}}\right)_{2} \mathrm{SiO}_{4}$ : Its relationship to the $520 \mathrm{~km}$ seismic discontinuity. Earth Planet. Sci. Lett. 351-352, 115-122 (2012).

69. Núñez-Valdez, M., Wu, Z., Yu, Y. G. \& Wentzcovitch, R. M. Thermal elasticity of $\left(\mathrm{Fe}_{\mathrm{x}}, \mathrm{Mg}_{1-}\right)_{2} \mathrm{SiO}_{4}$ olivine and wadsleyite. Geophys. Res. Lett. 40, 290-294 (2013).

70. Núñez-Valdez, M., Umemoto, K. \& Wentzcovitch, R. M. Fundamentals of elasticity of $\left(\mathrm{Mg}_{1-\mathrm{x}}, \mathrm{Fe}_{\mathrm{x}}\right)_{2} \mathrm{SiO}_{4}$ olivine. Geophys. Res. Lett. 37, L14308 (2010).

71. Hill, R. The elastic behaviour of a crystalline aggregate. Proc. Phys. Soc. Sect. A 65, 349-354 (1952).

72. Dziewonski, A. M. \& Anderson, D. L. Preliminary reference Earth model. Phys. Earth Planet. Inter. 25, 297-356 (1981).

73. Sinmyo, R. \& Hirose, K. Iron partitioning in pyrolitic lower mantle. Phys. Chem. Miner. 40, 107-113 (2013).

74. Brown, J. M. \& Shankland, T. J. Thermodynamic parameters in the Earth as determined from seismic profiles. Geophys. J. Int. 66, 579-596 (1981)

\section{Acknowledgements}

This work is supported by the Strategic Priority Research Program (B) of the Chinese Academy of Sciences (XDB41000000 and XDB18000000), Natural Science Foundation of China (41925017 and 41721002), and the Fundamental Research Funds for the Central Universities (WK2080000144). M.M.L. is supported by National Science Foundation (NSF) grants EAR-1849949 and EAR-1855624. S.M.D. acknowledges support from the new faculty startup funding of Michigan State University and NSF EAR-1664332. J. Li acknowledges support from NSF EAR2031149 and NASA NNX15AG54G. Some computations were conducted in the Supercomputing Center of the University of Science and Technology of China. 


\section{Author contributions}

W.Z.W. and J.C.L. conceived and designed this project. W.Z.W. performed the theoretical calculations. J.C.L., F.Z., S.M.D., and J.L. performed the experiments, M.M.L. conducted the geodynamic simulations. W.Z.W., J.C.L., and Z.F. wrote the paper, and all authors contributed to the discussion of the results and revision of the paper.

\section{Competing interests}

The authors declare no competing interests.

\section{Additional information}

Supplementary information The online version contains supplementary material available at https://doi.org/10.1038/s41467-021-22185-1.

Correspondence and requests for materials should be addressed to W.W., J.L. or Z.W.

Peer review information Nature Communications thanks Bijaya Karki, Wendy Mao and the other, anonymous, reviewers for their contribution to the peer review of this work. Peer reviewer reports are available.
Reprints and permission information is available at http://www.nature.com/reprints

Publisher's note Springer Nature remains neutral with regard to jurisdictional claims in published maps and institutional affiliations.

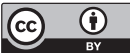

Open Access This article is licensed under a Creative Commons Attribution 4.0 International License, which permits use, sharing, adaptation, distribution and reproduction in any medium or format, as long as you give appropriate credit to the original author(s) and the source, provide a link to the Creative Commons license, and indicate if changes were made. The images or other third party material in this article are included in the article's Creative Commons license, unless indicated otherwise in a credit line to the material. If material is not included in the article's Creative Commons license and your intended use is not permitted by statutory regulation or exceeds the permitted use, you will need to obtain permission directly from the copyright holder. To view a copy of this license, visit http://creativecommons.org/ licenses/by/4.0/.

(c) Crown 2021 